\title{
The Protection of Particularly Vulnerable Victims in Hungarian National Law
}

\author{
BY Gergö CzÉDLI*
}

\begin{abstract}
This paper scrutinizes various levels and aspects of Hungarian criminal law from the perspective of particularly vulnerable victims, with regard to recent EU legislation. After a short introduction, Section 2 presents and compares several notions. The following sections present protective measures and instruments of substantive and procedural criminal law as well as the key regulations of the adjoining administrative field. At the end, the questions if Hungarian legislation has fully implemented the relevant EU Directive, and what further steps should be taken are addressed.
\end{abstract}

Keywords: victims' rights, particularly vulnerable victims, criminal law, criminal procedure

\section{INTRODUCTION}

European judicial cooperation has had a long history since the Convention on Extradition. ${ }^{1}$ Secondary legal sources of the European Union are increasingly regulating more diverse yet inter-connected fields and aspects of criminal law. Some directives, regulations and framework decisions deal with actual cooperation, while others focus on substantive or procedural matters. ${ }^{2}$ Latter ones blur the differences among national laws considering the field they govern, thus creating more or less universal instruments in European criminal law. There are also mixed-typed directives which have basically the same effect and bringing in some unique aspects. The Directive 2012/29/EU of the European Parliament and of the Council of 25 October 2012 on establishing minimum standards on the rights, support and protection of victims of crime, and replacing Council Framework Decision 2001/220/JHA (hereinafter simply the 'Directive'), the focus of this paper, is one of these directives.

European legislation is growing ever stronger roots into the soil of national law. This paper may be interpreted as a snapshot of this process taken from one particular angle; it shows how much and in what way the unique perspective and certain rules of the Directive are implemented in Hungarian national law. The ambition of this paper is to

* Judge; District Court of Szeged. E-mail: czedlig@csongradvb.birosag.hu

${ }_{1}^{1}$ European Convention on Extradition; Paris, 13.XII.1957.

2 A few examples on cooperative sources are 2002/584/JHA: Council Framework Decision of 13 June 2002 on the European arrest warrant and the surrender procedures between Member States; Council Framework Decision 2005/214/JHA of 24 February 2005 on the application of the principle of mutual recognition to financial penalties; Directive 2014/42/EU of the European Parliament and of the Council of 3 April 2014 on the freezing and confiscation of instrumentalities and proceeds of crime in the European Union, etc. For procedural matters see, for instance: Council Framework Decision 2009/299/JHA of 26 February 2009 amending Framework Decisions 2002/584/JHA, 2005/214/JHA, 2006/783/JHA, 2008/909/JHA and 2008/947/JHA, thereby enhancing the procedural rights of persons and fostering the application of the principle of mutual recognition to decisions rendered in the absence of the person concerned at the trial; for substantive ones see Council Framework Decision of 13 June 2002 on combating terrorism; Council Framework Decision 2003/568/JHA of 22 July 2003 on combating corruption in the private sector, etc. 
concurrently show the small and large details and perspective rather than showing the whole picture in details. The objectives of this paper are to show the results of implementation; to dig deeper in substantial law as well as presenting the scheme of the protection of highly susceptible individuals by criminal means and the procedural and administrative means of protection. Many of these rules are not inspired by the Directive; they are older achievements of a national evolution. The current implementation of the Directive only draws more attention to them.

The unique perspective is mentioned on purpose as substantive and procedural criminal law necessarily focuses on the perpetrator (the defendant) in any legal system. In this framework, the victim may only have a secondary role, if any. This main focus should not change; not even the Directive has such goal. However, the clear idea is to palpably strengthen the somewhat neglected position of the victim. In this sense, the aim is a swift change of perspective. ${ }^{3}$ The Hungarian legislature finally implemented the Directive on $1^{\text {st }}$ November $2015 .{ }^{4}$ The implementation is also a good occasion to present the state of this change with special regard to particularly vulnerable victims.

\section{NOTIONS OF VICTIM AND PARTICULAR VULNERABILITY}

The goal of turning more focus on the victim lies on a mixture of human rights, social, psychological and even purely logical grounds that the limited expanse of this paper does not allow to elaborate. It is, however, right to clarify in the beginning, who the victim is and what makes them particularly vulnerable.

According to the Directive, the victim is a natural person who has suffered harm, including physical, mental or emotional harm or economic loss which was directly caused by a criminal offence and in addition, a family member of someone whose death was directly caused by a criminal offence and who has suffered harm as a result of that person's death. ${ }^{5}$ The European Court of Human Right (ECHR), although completely independent from EU legislation, applies an almost identical notion. ${ }^{6}$

These notions are, nevertheless, not in use in Hungarian criminal law, only administrative regulations on supporting the victims of crime apply a similar definition (see Section 5). The vocabulary is different and more complex; the appropriate word 'áldozat' has all the general meanings of 'victim' but Hungarian criminal jurisprudence and legal practice, just like Hungarian itself, uses 'sértett' solely for the victim of a criminal offence. The victim, in a procedural sense, means the party whose right or lawful interest has been violated or jeopardized by the criminal offense. ${ }^{8}$ Thus, the victim means the aggrieved party

${ }^{3}$ For the genesis and a deeper analysis of the Directive see Rafaraci (2015) 215.

${ }^{4}$ Act CLI of 2015 on Amending Certain Acts to Implement Directive 2012/29/EU of the European Parliament and of the Council of 25 October 2012 on establishing minimum standards on the rights, support and protection of victims of crime, and replacing Council Framework Decision 2001/220/JHA (hereinafter: the 'Implementing Act').

5 Directive art 2. 1 a).

${ }^{6}$ Appendix of Recommendation $\operatorname{Rec}(2006) 8$ of the Committee of Ministers to member states on assistance to crime victims, art 1.1.

${ }^{7}$ It corresponds with the German distinction between 'das Opfer' and 'der Verletzte', although the German Code of Criminal Procedure (Strafprozessordnung, StPO) is not so consequent.

8 Section 51 (1) of Act XIX of 1998 on the Criminal Proceedings. The said act is hereinafter referred as 'Be.' 
in the criminal procedure that is not necessarily a natural person, but can be any legal entity e.g., the victim of a theft is always the owner of the taken property. Moreover, the Hungarian definition not only implies actual harm but the danger thereof as well. The latter is a significant achievement as the European definition of the victim may exclude victims of attempted offenses. For example, there is no victim under the Directive in case of an attempted murder when no injury is caused at all because the shot misses the victim or the poison is spilled instead of being drunk.

The Hungarian notion, on the other hand, also has its restrictions as it excludes family members, which does not prevent the heir of the victim from practicing their procedural rights. ${ }^{9}$ With respect to restrictions, it is important to see that judicial practice does not wholeheartedly embrace the idea of totally applying the said definition. A row of cases indicate that the victim may only act as a substitute private accuser if he can be considered the victim in a narrower, substantive sense as well. This means that the victim may only represent the charges himself, given all other conditions are met, ${ }^{10}$ if the exact legal definition of the offense contains either a 'passive subject' or a result. ${ }^{11}$

The passive subject, being a constituent element of the criminal act, needs further explanation. It is any person in the legal definition of a criminal offense whom the conduct of the perpetrator affects, in other words, they are the object of the criminal act, when the object is a person. ${ }^{12}$ Considering some offenses, the passive subject is necessarily the victim (the aggrieved party). For example, the perpetrator of a homicide is any person who kills another human being, ${ }^{13}$ hence this 'other human being' is the passive subject of the definition and the victim of the offense. In other cases, the passive subject is not always the victim. According to the criminal code, 'theft' means when a person takes an object to which he is not entitled from somebody else in order to unlawfully appropriate it. ${ }^{14}$ Among these constituent elements, this 'somebody else' is the passive subject of the criminal act, the person from whom the thing (the object of the criminal act) is taken away. This person is, however, not always the owner of the object, e.g., a stolen rented car. The result is an element easier to comprehend as it is indeed the result of the conduct, a factual change caused by the perpetrator (injury, damages, financial loss, etc.). ${ }^{15} \mathrm{~A}$ great deal of criminal acts does not contain either a passive subject or a result, which, under the permanent judicial practice meaning they do not have any victim in a substantial sense. ${ }^{16}$ Concerning all these

9 Be. s 51 (3).

10 The victim may act as a substitute private accuser, thus taking the prosecutor's position, in case the prosecutor or the investigating authority rejected the report, or terminated the investigation; the prosecutor filed formal charges only in respect of a part of the accusation; or the prosecutor dropped the charge [Be. s 53 (1)].

11 Opinion No. 90/2011 of the Criminal Chamber of the Curia (BKv. 90/2011.) II.1.

12 Belovics and others (2012) 178; Nagy (2004) 161.

13 Act C of 2012 on the Criminal Code (hereinafter 'Btk.') s 160 (1).

14 Btk. s 370 (1).

15 Belovics and others (2012) 183; Nagy (2004) 167.

16 According to case law these offenses include cruelty to animals, perjury, misuse of public information, forgery of administrative documents, abuse of authority (BH.2013.183, BH.2010.35, BH.2012.88, BH.2012.3, BH.2011.246.) Obviously, any of these offenses may still hurt or jeopardize the rights or interests of others. 
offenses, no one can act as a substitute private accuser and no one can act as a private party presenting a civil claim. ${ }^{17}$

Having collected three different notions of the victim, ${ }^{18}$ it is appropriate to consider who is a particularly vulnerable victim. There is no internationally accepted definition and there is no definition in Hungarian law. All notions presented here scratch the same surface either in continental legal systems in the practice of international forums, or in common law countries.

ECHR approaches the question from the state's positive obligation to protect individuals from inhuman treatment. ${ }^{19}$ Children and 'other vulnerable individuals' are, in particular, entitled to such protection. ${ }^{20}$ As for the EU, Council Framework Decision 2001/220/JHA (hereinafter simply 'the Framework Decision'), being the first, secondary legal source dealing with victims of crime, merely provides that member states shall ensure that particularly vulnerable victims can benefit from specific treatment best suited to their circumstances, without actually defining any factor of particular vulnerability. ${ }^{21}$ The Directive goes way further on that path giving indicative lists of reasons and traits of particular vulnerability, as well as determining what they might be exposed to secondary and repeat victimization, intimidation and retaliation. ${ }^{22}$ During the victims' individual assessment 'particular attention' shall be paid to those who suffered considerable harm due to the severity of the crime; those of crimes with a discriminatory motive related to their personal characteristics; and victims with relationship to and dependence on the offender. The Directive also gives some examples. The severity of the crime justifies the particular vulnerability of victims of terrorism, organized crime, trafficking in human beings; victims of hate crimes and gender-based violence are vulnerable because of discrimination; while the risk of vulnerability may be explained by dependence considering violence in a close relationship, sexual violence and exploitation. In other cases, the particular vulnerability rises entirely from the victim's person due to either disabilities, or minor age. ${ }^{23}$ Children are always presumed to have specific protection needs. ${ }^{24}$

Jenny McEwan divided particularly vulnerable victims into three main categories: children, disabled persons and victims in fear or distress ${ }^{25}$ and her categories can also be easily applied to the examples above. Across the Atlantic Ocean, US Federal Sentencing Guidelines group victims as unusually vulnerable due to age, physical or mental condition, or otherwise particularly susceptible to the criminal conduct, ${ }^{26}$ which basically also covers the same notion in different wording.

17 Victims of a crime may, of course, submit their claim for damages at the civil court any time but alternatively, the Be. allows them to sue the defendant for damages directly within the criminal procedure. In this case and when the court convicts the defendant as guilty, it also adjudicates the civil claim and obliges him to pay the damages for the victim [Be. s 335 (1)].

18 For a deeper analysis on different national and international definitions of the victim, see Görgényi (2005) 7.

19 Airey v Ireland (1981) Series A no 32 para 32.

20 A. v United Kingdom. (1998) 2 FLR 959 para 22; K.U. v Finland App no 2872/02 (2 Dec 2008) para 46.

21 Council Framework Decision 2001/220/JHA art 2 para 2.

22 Directive art 22 para 1.

23 Directive art 22 para $2-3$.

24 Directive art 22 para 4.

25 McEwan (2009) 370-5.

26 Garry (1993) 154. 
For the further purposes of this paper, victims falling under any of the descriptions written above shall be considered particularly vulnerable. The upcoming sections present legal instruments that specifically aim their protection, or have such effect.

\section{PARTICULARLY VULNERABLE VICTIMS IN SUBSTANTIVE CRIMINAL LAW}

The general part of the Hungarian Criminal Code (Btk.) deals with basic substantive principles, general provisions on the criminal act, substantive rules on penalties and some special regulations on soldiers and juveniles. It has not contained special provisions considering particularly vulnerable victims, until recently when an amendment of Btk., extended the rules of statute-barring with some extra protection for minor victims. This thereby ensured that no statute of limitation applies on sexual offenses punishable by an imprisonment of more than five years, if at the time when it was committed the victim was under the age of eighteen years. ${ }^{27}$ In addition to that, considering among others kidnapping, trafficking in human beings and sexual offenses, the limitation period shall not cover the duration until the time the victim reaches the age of eighteen years, or until the time that they would have reached that age. ${ }^{28}$

The special part of the Btk. contains several offenses that may only be committed against particularly vulnerable individuals, mostly but not exclusively children. Considering these offenses, the particular vulnerability of the victim itself justifies the criminalization of a conduct that is otherwise not punishable.

A further distinction can be made for children based upon the exact constitutive elements of the criminal act. Most conducts of sexual abuse may only be committed against victims under the age of 14 , as this offense includes only consensual sexual activities. ${ }^{29}$ (Non-consenting abuse, sexual violence, is a different offense with more severe punishment.) Other, mainly sexual, offenses may only be committed against a person under 18 years. Otherwise the same conduct does not constitute a criminal offense at all. This group includes one conduct of sexual abuse, when the perpetrator is in a position of trust, authority or influence over the victim, as well as one conduct of the felony of pandering, one of the felony of procuring for prostitution and two conducts of the felony of abuse of a minor. ${ }^{30}$ Inciting substance abuse, exploitation of child prostitution, child pornography and child labor are felonies where the victim is always a person under 18 years. ${ }^{31}$

A typical felony committed exclusively against a child is the 'abuse of a minor' which is committed by the holder of the custody over the minor by seriously violating the obligations arising from their duty and thereby endangering the physical, intellectual, moral or mental development thereof. ${ }^{32}$ This distinction has civil law grounds as not each individual under the age of 18 is a minor, married minors are considered to be of legal

27 Act LXV of 2014 on the Amendment of the Criminal Code for the Enhanced Protection of the Children s 1 (1); Btk. s 26 (3) c).

28 Act LXV of 2014 s 1 (2); Btk. s 28 (1a).

${ }^{29}$ Btk. s 198 (1)-(3). The perpetrator of this offense is also special, as for most conducts only a person over the age of 18 years is responsible.

30 Btk. s 198 (4); 200 (2); 201 (1) c); 208 (2).

31 Btk. s 181, 203, 204 and 209.

32 Btk. s 208 (1) 
age. ${ }^{33}$ Therefore the said offense may not be committed against a married and hence legally adult 17-year-old. ${ }^{34}$ The victim of the of the offenses 'preventing the exercise of visitation rights' and 'changing of the custody of a minor' may also only be a minor in its civil law sense. ${ }^{35}$

Some other specific offenses protect victims particularly vulnerable because of different reasons. This is a rather heterogeneous group. One form of plundering is basically a more severely punished theft against a person incapable of self-defense or whose ability to recognize or prevent the criminal act is diminished due to his old age or disability. ${ }^{36}$ The felony of 'failure to provide care' is the perpetrator's failure to perform his obligation to provide care for the victim who cannot care for himself due to his condition or old age, thereby endangering the latter's life, bodily integrity or health. ${ }^{37}$ Usury is conceptually committed by taking advantage of a victim in desperate need, usually of financial nature, which obviously makes him highly vulnerable. ${ }^{38}$ Degrading treatment of vulnerable persons is a rare misdemeanor relatively newly enacted that may be committed by exploiting the victim's vulnerability to engage in conduct to humiliate himself. ${ }^{39}$

Several offenses are considered to be a 'a bit tricky' in this respect. The victim of nonsupport is the parent or custodian of the child, as they are the person the maintenance should be paid, not to the child directly. ${ }^{40}$ However, this offense obviously affects the child as well. The victim of domestic violence can be almost any person living in the same household with the perpetrator yet the victim is always one of the weaker and more exposed family members in reality. ${ }^{41}$ The victim of the felony 'violation of family status' may be any individual yet it is hard to imagine any other victim than an infant. ${ }^{42}$ Violence against a member of a community may be committed against any national, ethnic, racial or religious group, or a certain community of the society on grounds of disability, gender identity or sexual orientation in particular, or any members of the said group. ${ }^{43}$ The targeted group may also include the national minority; ${ }^{44}$ in practice, however, victims of this offense belong to any form of minority which is not necessarily an ethnic, national or sexual one; for instance, it was 'the homeless people' in one case. ${ }^{45}$ The same applies to the endangered groups of the felony of inciting against a community. ${ }^{46}$

While the offenses above protect or usually protect particularly vulnerable persons, many others are more general, where the victim's vulnerability is a qualifying circumstance

33 Act $\mathrm{V}$ of 2013 s 2:10 (1). A person above the age of 16 and under the age of 18 years may only marry with the leave of the guardian authority.

34 BH.1981.51, BH.1984.265.

35 Btk. s 210, 211.

36 Btk. s 366 (1) c).

37 Btk. s 167.

38 Btk. s 381.

39 Btk. s 225.

${ }^{40}$ Btk. s 212 (1).

41 Btk. s 221/A.

42 Btk. s 213 (1). In several cases, the penalty is raised if the victim is a person under 18 years [Btk s $213(2)]$.

43 Btk. s 216.

${ }^{44}$ In one case, the defendants of Roma origin assaulted majority Hungarians due to ethnic reasons (Tribunal of Miskolc 4.Fk.1188/2011/217.)

45 Tribunal of Szeged 1.Fk.95/2013/57.

46 Btk. s 332. 
with more severe penalty. Distinction is usually made upon the age of the victim. Sexual violence has a complex classification system rendering more severe penalties to the offense if the victim is under the age of 18 years, and even more severe ones, if they are under 12 years. ${ }^{47}$ Similarly thereto, kidnapping, trafficking in human beings and sexual exploitation is punished more strictly if the victim is under 18 years and very severely if they are under $14 .^{48}$ Homicide is punishable by life imprisonment, if the victim was under the age of 14 and indecent exposure also has a similar qualifying circumstance, although with not as grievous consequences. ${ }^{49}$

Quite a lot offenses expand the enhanced protection to victims under 18 in their classification systems. This group includes aiding and abetting suicide, drug trafficking, drug possession, abuse of new psychoactive substances, abuse of performance enhancers, forced labor and violation of personal freedom. The victim's age results in a more severe penalty in all cases. ${ }^{50}$

Upon further analysis of the special part of Btk., one may discover that various forms of being underage is not the only qualifying circumstance considering the vulnerability of the victim. Moreover, the real novelty of the current criminal code is that it takes into consideration the victim's old age or disability as well for several offenses. It is a new qualifying circumstance of homicide, battery, robbery, embezzlement and fraud, if the victim's ability to defend himself or to recognize the crime is diminished due to their old age or disability. ${ }^{51}$ It is worth mentioning that not old age or disability itself establishes the qualifying circumstance but its possible effect of weakening the ability of self-defense. The legislature here seems to follow what English literature has already realized that the key element is not age, but the degree of vulnerability. Age may only increase the likelihood of vulnerability which arises from disability, lack of capacity, frailty, or in some cases through heavy dependency on the abuser. ${ }^{52}$ This might be why the legislature left to the practice to determine the boundaries of these factors, instead of setting up an age-limit and creating a definition on disability or referring to an existing regulation thereon.

Homicide and battery has another qualifying circumstance with regard to the particular vulnerability of the victim: the (complete) disability of self-defense..$^{53}$ These two qualifying circumstances may not concur. The courts consequently establish the latter qualifying circumstance only when the victim's ability to self-defense is completely missing, not diminished, due to their old age or disability. ${ }^{54}$ There is another crucial difference: Old age is, in the present state of scientific knowledge, a permanent state, while disability to selfdefense can be temporary, e.g. if the victim is tied up or simply asleep. ${ }^{55}$ Violation of personal freedom and sexual violence have a similar qualifying circumstance considering disability to self-defense as well; ${ }^{56}$ the latter, as mentioned above, also has qualifying

47 Btk. s 197 (3) a); 197 (2) (4) a).

48 Btk. s 190 (2) a), 192 (4) b) (5) b) d), 196 (2) a) vs. 190 (3) a), 195 (5) a) (6) a), 196 (3).

49 Btk. s 160 (2) i) and (4); 205 (2).

50 Btk. s 162 (2); 177 (1) a) b), 179 (1) a) b) (2); 184/A (1) a) b), 184/C (1) a) b); 185 (3) a) b)

(5); 193 (2) c) 194 (2) a) (3).

51 Btk. s 160 (2) k); 164 (4) c); (6) c); 365 (3) g); 372 (4) c); 373 (4) c).

52 Bridgeman and others (2008) 98.

53 Btk. s 160 (2) j), 164 (4) b) (6) b).

54 Criminal Uniformity Decision No. 3 of 2013 (3/2013. BJE) II. 11.

55 Criminal Uniformity Decision No. 3 of 2013 II. 10., Btk. s 459 (1) 29.

56 Btk. s 194 (2) b), 197 (1) b). 
circumstances for child victims. These two offenses, however, have no specific qualifying circumstance for old or disabled victims.

Finally, there is a fourth, less obvious layer of protection that may not be directly found in the Criminal Code. When imposing penalty, the court shall adjust it to the severity of the criminal offense, the degree of culpability, the social dangerousness of the perpetrator, and to other aggravating and mitigating circumstances. ${ }^{57}$ Aggravating and mitigating circumstances may be different from case to case; judicial practice, however, has elaborated an indicative system thereof. ${ }^{58}$ Several characteristics of the victim shall be taken into account as an objective factor influencing penalty, and this is where particular vulnerability may play a role as an aggravating factor. Such trait of the victim may be if they are old, sick, incapable of self-defense or in the need for protection (like children), pregnant or, in case of offenses against property, having financial difficulties. ${ }^{59}$

The (potential) vulnerability of the victim entails an aggravating factor in case of criminal attempt as well. On the other hand, this aggravating factor may only be applied when the perpetrator was or, in case of negligent act, at least should have been aware of the victim's particular vulnerability.$^{60}$ Judicial practice is also unanimous due to an interpretation of the principle ne bis in idem that no fact may be deemed as an aggravating or mitigating factor if the same circumstance is also either an element of the criminal act itself, or it constitutes a qualifying circumstance. ${ }^{61}$

It must also be noted that when applying the said aggravating factor, the term victim is used in its substantive sense (Section 2), thus including the person directly affected by the result as well. For any other substantive instruments represented in this chapter, the victim means the 'passive subject' only.

\section{VICTIMS IN CRIMINAL PROCEDURE}

Before inspecting the procedural position of the victim, for the purposes of this chapter, the victim shall be defined as the aggrieved party as represented in Section 2. This notion is way broader than the passive subject applied in the previous part of the paper but it is also to be kept in mind that judicial practice applies the said heavy restrictions.

Hungarian jurisprudence traditionally divides participants of the criminal procedure to main parties (defendant, counsellor, prosecutor) and secondary or 'side-parties', among others, the victim. ${ }^{62}$ In Nagypál's words, the procedural role of the victim is marginalized. From a historical main participant, he became a mere stunt, a weak witness and is often

57 Btk. s 79 (1).

58 Opinion No. 56 of 2007 of the Criminal Chamber of the Curia (BKv. 56/2007).

59 Opinion No. 56 of 2007 of the Criminal Chamber of the Curia III. 4.

${ }^{60}$ For instance, early stage of pregnancy may not be apparent to not only the perpetrator, but to the victim as well. In this case, the court may not take this fact into account as an aggravating circumstance.

${ }^{61}$ E.g. in case of the offense 'abuse of a minor', the victim is necessarily a child, so this means no further aggravating factor. Likewise, committing a homicide against a person incapable of selfdefense changes the legal classification and raises the punishment imposable already [Btk. s 160 (1) (2) j)], therefore the victim's incapability is no aggravating factor. Both phenomena help avoiding 'double jeopardy' in the sense that any single fact may be and shall be evaluated only once.

62 Cséka and others (2006) 40-1. 
treated that way as well, which may often contribute to secondary victimization. ${ }^{63}$ From these words, it is important to see that the position of the victim inevitably mingles with the position of the witness, which also applies to their protection.

The Code has very few specific provisions on particularly vulnerable victims so it is necessary to see first how victims are treated in general. The victim, heard as a witness or not, has a few general rights such as being present at procedural actions and inspecting the documents of the case affecting them (unless the act provides otherwise); filing motions and observations; obtaining information on their rights and obligations; and, against certain decisions seeking legal remedy. ${ }^{64}$ Another new provision is that a person of their choice may also be present at their hearings. ${ }^{65}$

The victim, as seen in Section 2, may also submit a civil claim, in which case they are called 'private party'. ${ }^{66}$ All these rights may also be exercised via a representative. ${ }^{67}$ Although this instrument is most commonly used and courts oblige the defendant to pay indemnification whenever requested by the victim, in reality, only 4 to 6 percent of the damages caused by criminal offenses is indeed recovered in or after the criminal proceedings ${ }^{68}$ In the rest of the cases, the convict fails to voluntarily pay and execution is either not initiated or remains inefficient.

Aside from being an important witness, the victim may play a more significant role when acting as a private accuser or a substitute private accuser. ${ }^{69}$ In both cases, the victim represents the charges thereby quasi uniting the position of the victim and the prosecutor. ${ }^{70}$ Being a substitute private accuser gives the victim a very strong procedural position, as they may in this case exercise almost full powers of the prosecutor given that the latter did not submit an indictment for several reasons. ${ }^{71}$ There is no surprise that prosecutors considered this instrument with some skepticism before it entered into force. ${ }^{72}$

The instruments of protection mostly target the witness that can actually also be the victim of the crime. The goal of protection is to guard the witness's life and freedom so that they can fulfill ones duty on giving a testimony without intimidation. ${ }^{73}$ The mildest and most common means thereof is treating the personal date of the witness confidentially, ensuring that only the authorities learn their whereabouts. ${ }^{74}$

A specially protected witness is a much stronger and rarer instrument of protection. In this case, the person of the witness is totally unknown to the defendant (and his counsellor), therefore the former is interrogated exclusively by the investigating judge and only an extract of their statement is attached to the case-file, while the protocol of the

63 Nagypál (2011) 24.

${ }^{64}$ Be. s 51 (2). For a more detailed catalogue of the victim's procedural rights, see Kiss (2009) $63-8$.

65 Be. s 184 (2); Directive art 20.

${ }^{66}$ Be. $\mathrm{s} 54(1)$.

67 Be. s 56 (1) (5).

68 Lencsés (2008).

69 Nagypál (2011) 24.

70 Tóth (2003) 506.

71 See note 10. Participation of a legal representative is compulsory.

72 Kiss (2003) 14.

73 Be. s 95.

74 Be. s 96. Confidential data handling is, in practice, granted whenever the witness asks for it, although courts and other authorities could reject such request if they consider it inappropriate. 
hearing is confidential. ${ }^{75}$ This instrument violates the principle of immediacy, as the witness remains hidden not only from the defendant's side, but, to some extent, from the judge as well. ${ }^{76}$ On the other hand, this solution may undermine the defendant's right to fair trial if the verdict is based on anonymous testimonies and no other evidence supports guiltiness. ${ }^{77}$ It is worth mentioning that no provision of $B e$. prevents this from happening, ${ }^{78}$ which would certainly violate defendant's rights. ${ }^{79}$ For all the said disadvantages, special protection usually provides enough safety to the witness who only meets the investigating judge during the whole process, most likely two times at most. ${ }^{80}$ Unfortunately, the victim cannot always become a protected witness, as the person is likely to be known to the defendant.

Physical protection of the victim and other parties to the procedure is not in details regulated by the Code, however the court, the prosecutor or the investigating authority may initiate the personal protection of any participant of the procedure. ${ }^{81}$ Hungarian law also provides a Defense Program for Witnesses, which may include building up a complete new identity for the witness. ${ }^{82}$

In addition to all the means above, several further procedural provisions might also help protecting the witness, as various authors indicated. A written statement is usually requested from a witness who cannot appear in person, but it also avoids direct connection between the witness and the defendant. ${ }^{83}$ For the same reason, interrogating via video-conference may also have the same effect, ${ }^{84}$ although Hungarian courts are technically unprepared for its wide application. Pretrial detention may be ordered on the ground that the defendant is assumed to try to impede, hinder or endanger collecting evidence by means of influencing or intimidating the witness, ${ }^{85}$ which makes detention also an alternative and strong means of witness protection. ${ }^{86}$ As an alternative of detention, a restraining order can also protect the victim. ${ }^{87}$ The omission of confrontation between witness and defendant can also spare the former from direct contact or intimidation. ${ }^{88}$ The court may try in camera, among other reasons, to protect the minor participant or any other party. ${ }^{89}$

Many of these means separate the defendant and witness. Although the former always has at least a right to motion questions and this paper has simply not enough expanse for a deeper analysis, it is important to see the possible and dangerous conflict with defendant

75 Be. s 97, 213 (2).

76 Boros (2012) 4.

77 Bérces (2012) 5.

78 Szabó (2014) 35.

79 See for example: ECHR Kostovski v The Netherlands App no 11454/85 (20 November 1989) para $37-45$.

${ }^{80}$ The first interrogation by the investigating judge is during the investigation. In the trial phase, the defendant may read the extract of the testimony and motion further questions. If the judge accepts this motion, he requests the investigating judge for a new hearing. This hearing might be repeated a few times in theory, but it is highly improbable that the panel trying the case would request further hearings a second (third, etc) time.

81 Be. s 98. Details are provided in Government Regulation No 34 of 1999 (26 February).

82 See Act LXXXV of 2001.

83 Tremmel (2008) 146.

${ }^{84}$ Kertész (2001) 31.

85 Be. s 129 (1) b).

86 Csányi (2010) 218.

87 Szabó (2012) 90.

88 Csányi (2010) 217.

89 Be. s 237 (2) b)-c); Csányi (2010) 220. 
rights. Too much separation can easily undermine the right to fair trial, as a number of studies indicate. ${ }^{90}$ The latest series of ECHR decisions indicate that the key to preserve the fairness of the procedure is to provide sufficient opportunity for the defense to challenge a witness's testimony. ${ }^{91}$ Speaking of separation, the Implementing Act also amended the $\mathrm{Be}$. providing that the authorities shall seek to avoid unnecessary contact between victim and defendant. ${ }^{92}$

The Framework Decision provided without much explanation that the member states 'shall seek to promote' mediation 'when appropriate. ${ }^{93}$ Being more elaborate in general, the Directive realized the potential jeopardies of restorative justice and put its focus on proper safeguards. ${ }^{94}$ According to the Directive, mediation shall only be used if it is in the interest of the victim, ${ }^{95}$ while $\mathrm{Be}$. has a more complex aim of improving the compensation of the victim and the compliance of the defendant. Despite the different emphasis, it is clear that the main advantage of successful mediation is the fast recovery of the victim's damages and the $B e$. applies the necessary safeguards in favor of the victim, as the procedure may only be commenced upon their voluntary consent. Mediation is only successful when the defendant and the victim reaches a voluntary agreement and the criminal procedure is only terminated when this agreement is indeed fulfilled. ${ }^{96}$

The scope of mediation has been slightly expanded in several steps since its introduction. ${ }^{97}$ However, there is no place for mediation in private accusation cases, although this is where the victim otherwise truly control the procedure. According to the Curia, the pretrial hearing aimed at settling the dispute has the same function. ${ }^{98}$ The free negotiating and agreement gives considerable liberty to both parties but it also implies the possibility that the victim accepts an indemnification lower than the actual damages but it ensures some reimbursement at all. ${ }^{99}$

As for particularly vulnerable victims, the $B e$. traditionally has quite many special provisions on child witnesses under 14 years who may be heard at all in case the evidence obtained from their testimony cannot be substituted by other means. ${ }^{100}$ Furthermore, such witness and any other person incapable of understanding the significance of the denial of testimony due to their mental state, may be only heard upon the consent of the holder of the custody who, on the other hand, may be present during the hearing. ${ }^{101}$ Child witnesses are also consequently separated from the defendant as they may not attend the trial and they are heard by the investigating judge or the investigating authority. ${ }^{102}$ Subsequently, they may

90 E.g. König and others (2013; Kádár (2011); to some extent Schünemann (2009).

91 E.g. König and others (2013; Kádár (2011); to some extent Schünemann (2009).

92 Be. s 62/B (1).

93 Framework Decision art 10.

94 Directive Preamble s 46, art 12.

95 Directive art 12 1. (a).

96 Be. s 221/A. Might be worth mentioning at this point that the recovery of the victim's damages is also evaluated as a mitigating practice in substantial law, even when it is partial or regardless of the perpetrator's conduct [see Görgényi (2006) 132-4].

${ }^{97}$ Now it may be applied to misdemeanors and felonies punishable by an imprisonment of no more than 5 years against life, physical integrity or health, personal freedom, human dignity and fundamental rights, property or intellectual property rights; and any traffic offense [Btk. s 29 (1)].

98 Opinion No. 3. of 2007 of the Criminal Chamber of the Curia (3/2007 BKv.) II/a.

99 Róth (2009) 144.

100 Be. s 86 (1).

101 Be. s 86 (2) (3).

102 Be. s 207 (4), 213 (2) (3). 
only be re-interrogated on trial in case it is ultimately necessary, provided that they have reached the age of 14 by that time. ${ }^{103} \mathrm{~A}$ witness under 14 may only be confronted with the defendant or another witness, if the situation does not intimidate him, ${ }^{104}$ so a child's confrontation is also, in Fenyvesi's words, 'an undesirable method in general.' 105

Even before the implementation, a relatively new general rule applied on any individual, being a victim or in any other position, under the age of 18 years or being blind, speech or hearing impaired, or mentally disabled. To all these persons, legal warnings shall be composed in a way so that they can understand it. ${ }^{106}$ The Implementing Act, amending the Code further, also obliged the authorities to make sure that the person affected actually understood the warnings and to explain them when necessary. ${ }^{107}$ Prior to the Implementing Act, only one group of particularly vulnerable victims, namely the victims of certain serious crimes had the right to be notified of the defendant's (convict's) release from prison upon their request. ${ }^{108}$ The Implementing Act turned this into a general right for any victims. ${ }^{109}$

The greatest achievement of the Implementing Act was obviously that it has finally introduced the instrument of particularly vulnerable victims (translated somehow as 'victims of specific needs'). ${ }^{110}$ The act gives no definition but instead provides that the authorities shall constantly monitor if the victim is particularly vulnerable based upon either their personal conditions or the circumstances of the offense. ${ }^{111}$ Should the authority come to the conclusion that the victims are indeed particularly vulnerable, it should proceed with 'maximum consideration'. It shall record their hearing, interrogate them via the investigative judge, through video-conference or in camera, whenever these solutions do not conflict with fair procedure. ${ }^{12}$ Another novel provision provides that victims of sexual crimes or family violence shall be interrogated by a person of the same sex during the investigation if so desired. ${ }^{113}$

\section{ADMINISTRATIVE MEANS OF SUPPORT IN A NUTSHELL}

The aid for victims of crime is regulated by a separate statute Act CXXXV of 2005 (hereinafter 'Ást.') which contains a broader notion of the victim, as mentioned Section 2, For the application of Ást., the victim means any victim of crime in its procedural sense; any victim of minor offenses against property and any other natural person who suffered physical, mental or emotional harm or economic loss as a direct consequence of a criminal offense or a minor offense against property. ${ }^{114}$ This is the closest Hungarian definition of the

103 Be. s 293.

104 Be. s 124 (3).

105 Fenyvesi (2008) 36.

106 Be. s 62/A cf Directive art 3 para 1-2.

107 Implementing Act s 7.

108 The victim shall also be informed of this right. [Be. s 51 (4), 214 (4), 261 (4) cf Directive art 6. para 5-6].

109 Implementing Act s 4 (4).

110 Implementing Act s 8; Be. s 62/C.

111 Be. s 62/C (1) (2); child victims are presumed to be particularly vulnerable, as seen already in the Directive at Chapter 2.

112 Be. s 62/C (3) (4).

113 Be. s 86/A.

114 Ást. s 1 (1). The act, as a distinction, uses the Hungarian term 'áldozat'. 
victim in line with EU law however it is only applied by the said act, ${ }^{115}$ or, in Ilona Görgényi's words, it is a combination of the definitions of the $B e$. and the Framework Decision. ${ }^{116}$

The act provides broad access to information and legal advice for the victims, considering not only their procedural rights and duties, but aid and support available, governmental and non-governmental organizations they may contact, means of avoiding repeated victimization, etc. ${ }^{117}$ The victim support service i.e. the governmental organization dealing with such cases, may also provide two forms of financial assistance. Immediate financial aid may be paid for the victim to cover their food, shelter, clothing, travel and healthcare costs, should they be not able to bear them as a consequence of the offense. ${ }^{118}$ The victim, based on their social circumstances, may also be entitled to a financial compensation that may be total or limited depending on the amount of the damage caused by the offense. ${ }^{119}$ Upon request, the authority proceeding with the criminal or minor offense case shall provide a certificate within a day that contains all the necessary information for the victim support service to decide. ${ }^{120}$ A novel feature of the Implementing Act is the inclusion of psychological support services. ${ }^{121}$

From another perspective, services provided by the victim support service may be divided into various forms of victim-care assistance every victim is entitled to, and to compensation that is provided only on a means tested basis. ${ }^{122}$

Victim support services have grown quite popular among the victims over the years. As a flipside, some research and statistical data raise suspicions that the prospect of financial support attracts fraudulent victims as well, thus these subsidies, and immediate financial aid in particular, gain an unwanted social function. ${ }^{123}$

The implementation did not leave the text of the Ást. untouched, yet it still does not have any expressed provision on particularly vulnerable victims. As some improvement, however, the victim support service shall henceforth individually assess the victim's specific needs and offer services in accordance with those. ${ }^{124}$

\section{EVALUATION OF THE CURRENT SYSTEM AND CONCLUSIONS}

The evaluation of Hungarian criminal law from the very special perspective of this paper should start at its substantive level. The Btk. is a rather strict criminal code when compared to other European countries; ${ }^{125}$ offenses against susceptible individuals are punished even

115 Cf Directive art. 2. 1 a) as described in Section 2.

116 Görgényi (2008) 63.

117 Ást. s 24-26/A, 34 cf Framework Decision art 4.

118 Ást s 4, 27.

119 Ást. s 7. These provisions implement Council Directive 2004/80/EC of 29 April 2004 relating to compensation to crime victims.

120 Ást. s 11.

121 Ást. s 26/B; Implementing Act s 30.

122 Schweighart (2009) 57-61.

123 Kerezsi \& Kó (2008) 155.

124 Ást. s 23 (2).

125 For instance, one may see a deep, comparative analysis of the criminal sanctions of $11 \mathrm{EU}$ member states considering certain offenses in the European Commission's 'Study on Criminal Sanction Legislation and Practice in Representative Member States' (2014) see at link 1. 
more strictly and an amendment, as presented in Section 3 provides extra protection for children at the general level against the most serious crimes. Consequently, there is no any room for further enhancement.

The victim's procedural position is far worse. As Kiss remarked, the Be. regulates their rights at many separate parts, resulting in a 'chaotic picture' for lay people, therefore victims 'subsist at the periphery of the judicial system.' ${ }^{126}$ The author agrees with Szabó that it is merely a matter of time before the discrepancy between the legal notion of the victim and the practical interpretation thereof triggers another case at ECHR, ${ }^{127}$ even if the position of the Curia is that these rules unchanged for over a century have never required any further interpretation. ${ }^{128}$ An idea, which might not be the simplest one, is that this time the law should be adjusted to practice upon enacting a new definition for the aggrieved party, which would be identical to the restrictive procedural approach. This would make clear who may act as a private party and request damages, etc. Simultaneously and in order to fully implement the Directive, the legislature should introduce a new party to the procedure, another type of victim in the sense meant by the Directive ('áldozat' in Hungarian), and very carefully decide which rights may each victim exercise and which ones merely the aggrieved party.

Although the $B e$. proudly announces that it has been harmonized with the Directive, ${ }^{129}$ this implementation is still not at all perfect. No expressed provisions prevent victims from being questioned repeatedly, although, as an improvement, authorities shall at least strive on doing (without any consequence of failure). ${ }^{130}$ Although more and more special premises are adapted for hearing children, some other measures are still missing. There is no rule that interviews with a particularly vulnerable victim should be carried out by or through professionals trained for that purpose or that all such interviews should be made by the same person within one phase of the procedure at least. ${ }^{131}$

Another general remark is that one can see that almost all the protective measures for particularly vulnerable victims target the witness. These instruments are able to provide acceptable safety when applied properly but that protection should start earlier. Albeit criminal procedure is just one link in this chain that cannot solve everything, the author agrees with a comment from Schünemann that making it easier for the victim to testify is only the last step in protection. ${ }^{132}$ The above suggested separation of the victim and aggrieved party could make some space for improvement.

Even if the defendant is obliged within the criminal proceedings to pay damages to the victim, the costs and risk of executing such obligation on the defendant is still borne by the victim. According to Róth, the ideal solution would be from the victim's aspect if the execution of the compensation had priority over any other financial sanction (fine, costs of the proceedings, etc.) ${ }^{133}$ Agreeing with the direction of the idea, it must be emphasized that it is not easily achievable. By a mere amendment of civil execution rules, the legislature

126 Kiss (2003) 69.

127 Szabó (2014) 32.

128 Justification of 2009 n Criminal Uniformity Decision No 3 of 2004 (3/2004 BJE), Chapter I.

129 Be. s 608 (7).

130 Be. s 62/B (2); Directive art 20.

131 Directive art 23 para 2.

132 Schünemann (2009) 388.

133 Róth (2011) 164. 
could and should grant priority to the victim's damages over procedural costs. ${ }^{134}$ Fines are, on the other hand, turned into imprisonment upon nonfeasance and this is why convicts are way more likely to pay the fine than costs and damages. The only step might and needed to be taken in this situation is to introduce a form of guarantee from the state at the expense of the fines voluntarily paid. Resultantly, if the fine has been paid the state would advance or partly advance the damages of the victim from it and then try to execute damages as a civil claim on its own. ${ }^{135}$

While the introduction of mediation was surrounded by some skepticism, ${ }^{136}$ it has proved to be a working instrument over the years following some minor amendments and has not taken that 15 to 20 years as predicted by Bérces. ${ }^{137}$ Rules of mediation live up to EU requirements and therefore the scope of it should not be extended to more serious crimes. Still there are ways to evolve. It is a rather old idea from jurisprudence that ensuring mediation for private accusation cases would help the workload of the courts diminish while the culture of dispute resolution through direct negotiations could become more widespread in the society. After all, these cases are typically those where criminal sanctions cannot solve the core conflict. ${ }^{138}$ The agreement reached through mediation should be null and void if the agreed compensation does not reach the victim's actual damages. This amendment would protect, above all, those particularly vulnerable victims that are scared of or dependent on the defendant. ${ }^{139}$

This paper has been written during the early steps of the codification of Hungary's new criminal procedure statute. According to the government's official concept thereof, the new act should, among others, fully implement the Directive. ${ }^{140}$ The government also realized that as a basic guideline of re-codification, more emphasis and attention shall be devoted to the victim, supporting them by any means available. ${ }^{141}$ The document also senses that redrafting of the notion of the victim should be 'considered' and calls for a swift and - in the author's opinion - inevitable change of attitude. ${ }^{142}$ From the legislature's side, it means that the traditional view of the interests of the defendant must be adjusted in the light of the legitimate interests of victims. ${ }^{143}$ From the practitioners' side, it entails the need of training, another objective of the Directive. ${ }^{144}$ And it is also a matter of self-training and devotion any written law is no more and no less than what we make it.

134 Act LIII of $1994 \mathrm{~s} 165$ (1). Now it is exactly the other way round.

135 This solution has some costs to the state, but losing a part of the fines imposed in criminal sentences should be irrelevant from the financial perspective of the state, especially when compared to the interest of the victim.

136 Tarr (2006).

137 Bérces (2009) 153.

138 Törzs (2008) 240.

139 Alternatively, the consent of the mediator could be required for the validity of such agreement.

140 ‘Az új büntetőeljárási törvény szabályozási elvei’ (2015) see at link 2, 7.

141 'Az új büntetőeljárási törvény szabályozási elvei' (2015) see at link 2, 10.

142 'Az új büntetőeljárási törvény szabályozási elvei’ (2015) see at link 2, 11.

143 McEwan (2009) 370.

144 Directive art 25. The very idea of this paper was conceived when I had the opportunity to take part on a series of trainings organized by the judicial academies of the Visegrád countries, with the support of the EU. 


\section{LITERATURE}

Belovics, E. et al., Büntetőjog I (HVG-ORAC 2012).

Bérces, V., 'A resztoratív igazságszolgáltatási koncepció érvényesülésének lehetőségei büntetöügyekben - különös tekintettel a mediációra és annak hazai szabályozására’ (2009) V/3 Iustum Aequum Salutare 137-54.

Bérces, V., ‘A védő kérdezési jogának gyakorlásával kapcsolatos kérdések’ (2012) 4 Jogelméleti Szemle 3-14.

Boros, R. ‘A különösen védett tanú a Magyar büntetőeljárásban' (Jogi Fórum 10 January 2012).

Bridgeman, J. et al. (eds), Responsibility, Law and the Family (Ashgate Publishing Limited 2008).

Csányi, Cs., 'A tanúvédelem és a szervezett bünözés összefüggései és a tanúvédelem egyes eszközei' (PhD thesis, Pécsi Tudományegyetem/University of Pécs 2010).

Cséka, E. et al., A büntetőeljárási jog alapvonalai, Vol I ( $2^{\text {nd }}$ edn, Bába Kiadó 2006).

Fenyvesi, Cs., Szembesités - Szemtöl szembe a büntetöügyekben (Dialóg Campus 2008).

Garry, J., 'Why Me: Application and Misapplication 3A1.1 the Vulnerable Victim Enhancement of the Federal Sentencing Guidelines' (1993) 79 Cornell Law Review 143-82.

Görgényi, I., 'A bünelkövető általi jóvátétel értékelése a büntetéskiszabás során és a büntető kódexben Magyarországon' in J Szabadfalvi (ed), Facultas nata: Ünnepi tanulmányok a miskolci jogászképzés 25. évfordulójára (Bíbor Kiadó 2006) 131-48.

Görgényi, I., 'Az áldozat fogalma és megítélése' in Zs Rózsahegyi (ed), Áldozatsegités Európában (Igazságügyi Minisztérium 2005) 7-32.

Görgényi, I., ‘Az áldozattá válás megelözése’ (2008) 15 Ügyészek Lapja 59-70.

Kádár, H. 'Az anonim tanúk az Emberi Jogok Európai Bíróságának Joggyakorlatában. A közvetlenség elvének korlátozásai.' (2011) 2 Scientia Iuris 23-40.

Kerezsi, K., Kó, J., Az Áldozatsegítő Szolgálat hatékonyságvizsgálata: Második szakasz: Összefoglaló jelentés (2008).

Kertész, I., 'A még különösebben védett tanú' (2001) 11 Belügyi Szemle 29-45.

Kiss, A., 'A sértett hátrányos helyzete a büntetőeljárásban' (2003) 2 Ügyészek lapja 5-18.

Kiss, A., 'Új szemlélet a büntetőeljárásban' in A Borbíró et al. (eds), A kriminálpolitika és a társadalmi bünmegelözés kézikönyve - 2009, Vol II (Fresh Art Design Kft 2009).

König, T. et al., 'The European Union's Approach towards Child Victim Testimonies in Criminal Proceedings Compared to the Right to Fair Trial' (2013) 67/4 Journal of Politics and Law 14-34.

Lencsés K., 'Olcsóbb, mint a börtön' (interview with Katalin Gönczöl, former secretary of the Ministry of Justice Népszabadság, Budapest, 22 April 2008).

McEwan, J., 'The Testimony of Vulnerable Victims and Witnesses in Criminal Proceedings in the European Union' (2009) 10 ERA Forum 369-86.

Nagy, F., A magyar büntetöjog általános része (Korona Kiadó 2004).

Nagypál, Sz. 'A büntetőjogi közvetítés (mediáció) jogelmélete' (2011) 1 Iustum Aequum Salutare $15-36$.

Rafaraci, T. 'New Perspectives for the Protection of the Victims in the EU' in S Ruggeri (ed), Human Rights in European Criminal Law (Springer International Publishing 2015) 215-25.

Róth, E., 'A kár megtérülésének egyéb formái' in A Borbíró et al. (eds), A kriminálpolitika és a társadalmi bünmegelözés kézikönyve - 2009, Vol II (Fresh Art Design Kft 2009) 139-54.

Róth, E., 'A sértett helyzete a büntetőeljárásban az Európai Unió elvárásainak tükrében' (2011) 6 Miskolci Jogi Szemle 155-67.

Schünemann, B., 'Protection of Children and Other Vulnerable Victims Against Secondary Victimisation: Making it Easier to Testify in Court' (2009) 10 ERA Forum 387-396.

Schweighart, Zs. 'Áldozatvédelem, áldozatsegítés és a büntetőjogi felelősségre vonás' (2009) 2 De iurisprudentia et iure publico 35-63.

Szabó, K. 'Kérdőjelek a büntetőeljárási törvény egyes rendelkezései kapcsán’ (2014) 1 Büntetőjogi szemle 31-36.

Szabó, K. Tanúvédelem a magyar büntetőeljárásban (HVG-ORAC 2012)

Tarr, Á., 'A kárhelyreállítás jelene és jövője a magyar büntetőeljárásban' (2006) 2 Debreceni Jogi Mühely 3-22.

Tóth, M. (ed), Büntetőeljárásjog (HVG-ORAC Budapest 2003). 
Törzs, E. 'Ki mit közvetít? - Jogértelmezési kérdések a büntetőügyekben alkalmazható közvetítői eljárással kapcsolatban' in K Iványi (ed), A büntetöügyekben alkalmazható közvetitői tevékenység bevezetésének tapasztalatai Magyarországon (Partners Hungary Alapítvány 2008) 229-49.

Tremmel, F., 'A tanúvédelem hazai körképe' (2008) 1 JURA 144-50.

\section{LINKS}

1. European Commission's 'Study on Criminal Sanction Legislation and Practice in Representative Member States' <http://ec.europa.eu/justice/criminal/document/files/sanctions_delivery_en.pdf $>$ accessed 16 June 2016

2. 'Az új büntetőeljárási törvény szabályozási elvei', the proposal of the government accepted on 11 February 2015 < http://www.kormany.hu/download/d/12/40000/20150224\%20IM\%20el\%C5\%91 terjeszt $\% \mathrm{C} 3 \% \mathrm{~A} 9 \mathrm{~s} \% 20 \mathrm{az} \% 20 \% \mathrm{C} 3 \% \mathrm{BAj} \% 20 \mathrm{~b} \% \mathrm{C} 3 \% \mathrm{BCntet} \% \mathrm{C} 5 \% 91 \mathrm{elj} \% \mathrm{C} 3 \% \mathrm{~A} 1 \mathrm{r} \% \mathrm{C} 3 \% \mathrm{~A} 1$ si $\% 20$ t $\%$ C3\%B6rv\%C3\%A9ny\%20szab\%C3\%A1lyoz\%C3\%A1 si\%20elveir\%C5\%911.pdf> accessed 11 September 2015 p 7. 